\title{
1. Introduction: framing the methodology of justice, injustice and Brexit
}

\author{
Tawhida Ahmed and Elaine Fahey
}

\section{INTRODUCTION}

As the heated discourses surrounding the UK's EU referendum vote demonstrated, a wealth of diverse, diverging and contradictory perspectives exist around what Brexit constitutes and the putative or likely impact Brexit will have upon individuals and groups. For some, the calling of a referendum itself was democratically unjust; to others the referendum epitomised the very essence of a just democratic process for both the UK and the EU more widely. Likewise, extensive discussions and views continue to be espoused on the pouring of resources into the EU and how this hinders or furthers justice in terms of allocation and redistribution of resources. Relatedly, the justice and injustice of the sharing of these and other resources, amongst British citizens, EU citizens, and others in the UK territory, brings up questions concerning what kind of British, European and indeed global society we want, envisage and, is most just. It brings to the fore questions about the value and structure of the state, in a world which has, of recent decades, been more vividly constructed as globalist, interconnected, and as being of 'beyond the state'. Brexit provokes us to consider the consequences of global governance for justice at national and international levels, as well as vice versa, the effects of national level ideals of justice on global governance. It might invite significant reflections on what 'new' perspectives for Europe are or might be, what 'justice' is for the EU and where it fits into the EU's manifold other crises - but this is not necessarily the same question as asking about justice and injustice and Brexit. ${ }^{1}$

1 Cf J. Habermas, “New perspectives” on Europe' Social Europe October 2018 or G. De Burca, D. Kochenov and A. Williams (eds), Europe's Justice Deficit (Hart, 2015). 
This book and introductory chapter explores how Brexit is intertwined with ideas of justices and injustices. The EU is the epitome of a globalised world: an organisation with a huge number of members, partners and collaborators, seeking to further common goals, with pooling of resources to address shared concerns. Much attention has been traditionally paid to the question of justices or injustices of such globalisation as regards the impact that entering into, or increasing, such global relations has on individuals or groups (as well as legal entities). This chapter intentionally analyses the reverse: that is the question of what justice is brought about by (the UK's) withdrawal from globalisation (in the sense of its exit from EU membership).

This chapter thus considers in section I the issues of Brexit and justice as a challenge of concept and methodology; section II a challenge in terms of geographical boundaries and sovereignty; section III a challenge in terms of the framing of the state; and section IV a challenge of actors, subjects and objects. Each section offers questions for critical thought for both authors and readers alike, before bringing this together briefly in section $\mathrm{V}$. The last section finally offers some concluding reflections, after introducing readers to the overarching themes and authors' chapters.

\section{FRAMING BREXIT AS A CONCEPTUAL AND METHODOLOGICAL CHALLENGE}

Justice discourses have consistently pervaded the UK's participation in the EU as to whether the UK's membership of the EU provided forms of justice or injustice to UK and other citizens, or for different policy areas. The UK joined the EU in 1972. In the 1970s and 1980s, issues of injustices raised included concerns around the upholding of parliamentary sovereignty, ${ }^{2}$ but also opposition to EU economic policy. ${ }^{3}$ Despite the 1975 British referendum vote to remain in the EU, over the next four decades, opposition to EU membership grew and also became intertwined with the politics of a range of domestic concerns for the British public, which emerged prior to the Brexit context.

\footnotetext{
2 Andy Mullen and Brian Burkett, 'Spinning Europe: Pro-European Union Propaganda Campaigns in Britain 1962-1975' (2005) 76 (1) The Political Quarterly 100-13, 107; Robert Shepherd, 'Leadership, Public Opinion and the Referendum' (1975) 46 (1) The Political Quarterly 25, 28; Conservative Research Department, 'Yes to Europe, The Conservative Guide for the 1975 Referendum Campaign' 96 28-52, 55-66 www.cvce.eu/obj/yes_to_europe_the_conservative_guide_for_the_1975 referendum_campaign-en-639fb9e $\overline{5}-\mathrm{ca}_{77}-465 \overline{3}-8 \overline{870}-6 \mathrm{cfd} 7 \mathrm{f} 0782 \mathrm{c} 6 . \mathrm{html}, \overline{-}$ accessed $\overline{2} 0$ October 2018 .

3 Robert Shepherd, 'Leadership, Public Opinion and the Referendum' (1975) 46 (1) The Political Quarterly 25, 28.
} 
Nonetheless, membership of the EU was also seen to have raised the prospects of justice for many groups in the UK, not least women, and third-country (EU or non-EU) nationals. While not having full control over redistribution of goods and resources across the EU, the EU did provide the UK with a strong framework of non-discrimination, thus extending the capacity of UK nationals (and those of other EU citizens) to live a 'good life' within and beyond the territorial boundaries of their country of nationality. ${ }^{4}$

Conventional perspectives on justice in a globalised world focus on the effect of globalised relations on a substantive topic and/or the effects of an increase in such relations. With particular regard to Brexit, we see a reverse perspective of questions relating to justice emerge: that is what issues of justice does withdrawal from globalisation bring about? 'As an ethical concept, justice belongs to the realm of normative judgements about right and wrong, good and bad' ${ }^{5}$ This right or wrong or good or bad is about what is owed to others. Thus, like other questions of justice, perspectives on whether Brexit is 'just' is relational in nature. One's actions are just or unjust in regard to the impact they have on others. ${ }^{6}$ However, justice is a highly contested subject, comprising different areas as well as different approaches. Thus, whether Brexit is just or unjust (produces justices or injustices) depends on one's perspective on justice. As De Witte usefully points out, the main point of difference between alternative conceptions of justice lies in their starting point -i.e., what they see as the aims of justice. ${ }^{7}$

Brexit raises ostensibly categorised issues of justice for natural persons, and for legal persons, as well as for different policy fields such as employment, environment, health or education. Debates on the justice or injustices of Brexit have focused on, for instance, 'who' gets what in the substantive sense of material benefits or social goods. For example, as a sub-set of the immigration debate, Brexiteers saw EU membership as unfairly providing access to British goods to foreigners who were not seen as British, or as entitled. Strong views were expressed concerning pressures on resources and services such as housing, education and welfare benefits. ${ }^{8}$ The broad argument being that

\footnotetext{
4 Floris De Witte, Justice in the EU: The Emergence of Transnational Solidarity (OUP 2016).

5 Klara Helene Stumpf et al, 'A Conceptual Structure of Justice: Providing a Tool to Analyse Conceptions of Justice' (2016) 19 Ethic Theory and Moral Practice 1187, 1189.

6 Distinguished by Mill from duties that are ethically desirable, but not related to specific rights of others, e.g., charity.

7 Floris De Witte, Justice in the EU: The Emergence of Transnational Solidarity (OUP 2016) 19.

8 Rowena Mason, 'Priti Patel Warns of EU Migration Threat to UK Class Sizes' (The Guardian, 21 June 2016), https://www.theguardian.com/politics/2016/jun/21/priti
} 
the UK's participation in the EU as a global governance institution led to the overflow of EU migrants into the UK, and thus negatively affected the rights of the British to access goods and services - to which they felt they had a priority over others seen as migrants or as not belonging to the UK. ${ }^{9}$ These sentiments were exacerbated by the complexity of the shared EU-UK supranational governance order, whereby the state - and by extension its citizens - are by and large responsible for the funding and provision of certain goods, such as the NHS, education for under $18 \mathrm{~s}$, and welfare benefits. Yet, the decision to exit the EU has equally raised concerns about the loss of access to these goods for individuals who had crossed borders and set up lives in the UK, contributing taxes through employment, and embedding their family lives on UK soil.

Perspectives such as those above pertain strongly to distributive justice, in the sense of community relations, and structural justice in terms of the ways in which those community relations are structured. Thus the impact of Brexit on the NHS and other employment workforce is one example, ${ }^{10}$ as is the question of the democratic or representative fairness of the Brexit vote vis-à-vis those whom the decision affects. This brings into play questions such as the fairness of Brexit in human rights terms, as well as structurally in terms of the potential implications of the loss of access to (or detangling from) the EU courts and the EU Charter on Fundamental Rights (EUCFR). ${ }^{11}$ Amos argues that 'the real diminution in human rights protection actually lies further down the track when retained EU law is converted into domestic law, ${ }^{12}$ while others lament that 'a severe loss of rights will be seen as a result of leaving the EU.' 13 The UK government has excluded the EUCFR from the ambit of the EU Withdrawal Agreement, arguing that this is no loss as the Charter merely codified existing

-patel-warns-of-eu-migration-threat-to-uk-class-sizes, accessed 14 October 2018; also see Stuart Gietel-Basten, 'Why Brexit? The Toxic Mix of Immigration and Austerity' (2016) 42(4) Population and Development Review 673-80.

9 See Jonathon Portes et al. in UK in a Changing Europe at http://ukandeu.ac.uk/, accessed 14 October 2018.

10 'Brexit Likely to have Far-reaching Effects on UK Health and Health Service, Experts Suggest' (London School of Hygiene and Topical Medicine, 29 September 2017), https://www.lshtm.ac.uk/newsevents/news/2018/brexit-likely-have-far-reach ing-effects-uk-health-and-health-service-experts, accessed 14 October 2018.

11 'What does Brexit mean for Equality and Human Rights in the UK?' (Equality and Human Rights Commission, 20 July 2017), https:/www.equalityhumanrights .com/en/our-human-rights-work/what-does-brexit-mean-equality-and-human-rights -uk, accessed on 14 October 2018.

${ }_{12}$ Merris Amos, 'Red Herrings and Reductions: Human Rights and the EU (Withdrawal) Bill' (UK Constitutional Law Association), https://ukconstitutionallaw .org/2017/10/04/merris-amos-red-herrings-and-reductions-human-rights-and-the-eu -withdrawal-bill/, accessed 14 October 2018.

13 See Douglas-Scott in this book, Ch.7. 
rights. Dupré challenges this perspective, arguing that the Charter is dynamic and 'remarkably innovative'. ${ }^{14}$ Not only did the Charter establish an up-todate catalogue of human rights protection covering social, political, economic and social rights, it has also reached out to meet the needs of modern society, reflected through the development of rights relating to data protection and bioethics. ${ }^{15}$ As a result, the coverage of the document guarantees the potentially far-reaching protection to all people living in the EU. Besides the extensive coverage of rights, it is important to point out that the loss of the Charter will also result in the loss of a highly effective remedy of protection which has no equal in the current framework of rights protection in UK law. ${ }^{16}$ This is signified by important recent caselaw, ${ }^{17}$ which highlights that the Human Rights Act 1998 does not provide equivalent levels of protection as are guaranteed by the EU Charter. ${ }^{18}$

A particular concern has also been the implications of Brexit for gender justice. Improvements in the UK's gender equality, especially in the labour context, have resulted to a large extent from EU gender legislation. Fears now arise as to the UK's loyalty to this advancement once it leaves the UK, including in the areas of equal pay, pensions, part-time and maternity rights, as well as the disproportionate poverty impact on women in the midst of any economic downturn arising from the UK's exit from the EU. ${ }^{19}$

14 Catherine Dupré, 'Human Dignity is Inviolable. It Must be Respected and Protected: Retaining the EU Charter of Fundamental Rights After Brexit' (2018) 2 EHRLR 101-9.

15 'Why Do We Need the Charter?' (European Commission), https://ec.europa .eu/info/aid-development-cooperation-fundamental-rights/your-rights-eu/eu-charter -fundamental-rights/why-do-we-need-charter_en, accessed 18 October 2018.

16 Joelle Grogan, 'The Good, the Bad and the Ugly Arguments for Ditching the EU Charter of Fundamental Rights' (London School of Economics, Law Brexit Project, 1 February 2018), http://blogs.lse.ac.uk/brexit/2018/02/01/the-good-the-bad -and-the-ugly-arguments-for-ditching-the-eu-charter-of-fundamental-rights/, accessed 18 October 2018.

17 Benkharbouche $v$ Secretary of State for Foreign and Commonwealth Affairs [2017] UKSC 62.

18 See Joelle Grogan Chapter 5 in this book.

19 See e.g., Roberta Guerrina and Annick Masselot, 'Walking into the Footprints of EU Law: Unpacking the Gendered Consequences of Brexit' (2018) 17(2) Social Policy and Society 319-30; Collete Fagan and Jill Rubery, 'Advancing Gender Equality Through European Employment Policy: The Impact of the UK's EU Membership and Risks of Brexit (2018) 17(2) Social Policy and Society 297-317; Women's Budget Group and Fawcett Society, 'Exploring the Economic Impact of Brexit on Women' (March 2018), https://www.fawcettsociety.org.uk/Handlers/Download.ashx?IDMF= 049e3458-12b0-4d0f-b0a6-b086e860b210, accessed 20 October. 
One other example is that Brexit also provokes questions of climate justice. In this sense, Olawuyi talks of the loss of structural support in terms of a coordinated EU environmental framework for the UK, and the resulting fragmentation of that framework. This encourages injustices in divisions between countries and regions, e.g. ,as already exists 'especially the North-North divide and the North-South divide', ${ }^{20}$ leading to variances in environmental justice. Further, the UK's leaving of the EU creates concerns around energy poverty for the UK, since the EU had facilitated an integrated accessible energy market across the European region. ${ }^{21}$ As a result, the UK had increased its dependency on the EU market. ${ }^{22}$ Substantively, the UK can make less progress on its own than with the EU as a 'regional watchdog'. ${ }^{23}$ The EU also provides a forum for exchange of ideas and best practices. ${ }^{24}$

Both conceptually and methodologically, never has a question of international organisation law divided a society so much as this UK-EU 'Exit' decision. Its lamenters and opponents point to extreme benefits, seemingly diametrically opposed to its exponents and mostly out of proportion to its proponents, proclaiming freedom, sovereignty and a brighter future. The novelty of the issues surrounding exit from international organisations, whereby scholars increasingly investigate the procedural and substantive issues surrounding the unchartered and novel territories of exit indicate on a wholly practical level the novelty of such questions. Brexit has a range of binary frames: its vote; its negotiation sparring partners; its opposing view of divergence and convergence of EU and UK law going forward on socio-economic terms. To frame its potential impact or effects, at the time of writing, is highly problematic because largely hypothetical and mooted claims remain a constant. UK government impact case-studies, similarly to European Parliament impact studies remain mired in debates as to their contestability, their comprehensiveness, their accuracy. To frame Brexit first, arguably entails seeking an objective understanding of its meaning or its core.

20 Damilola S. Olawuyi, 'Advancing Environmental Justice in a Post-Brexit United Kingdom' from the Brexit: The International Legal Implications Series Paper No. 13 (Feb 2018) BIICL, 4, https://www.cigionline.org/sites/default/files/documents/Brexit \%20Paper\%20no.13_0.pdf, accessed 20 October 2018.

21 Directive 2009/72/EC requires removal of obstacles to cross-border interconnections and sale of electricity on equal terms within the EU: Directive 2009/72/EC of the European Parlament and of the Council of 13 July 2009 concerning common rules for the internal market in electricity and repealing Directive 2003/54/EC OJ L211/09.

22 In order to maintain this and not become isolated and energy poor, it will need to comply with EU energy law.

23 Olawuyi (n 20, 4-5.

24 Ibid., 5. 
The multidisciplinary nature of the Brexit analysis required arising from the tremendous legal, economic, political, socio-cultural, environmental and other related issues at stake complicates its divisive beginnings and the thorny issues thrown up by it further. One of the key features of understanding the methodological revolution in EU law has been its commitment to law-in-context and to a non-doctrinal understanding of law, politics and policy. A good example of the methodological issues involved in Brexit is also evidenced by the 'UK in a Changing Europe' research forum, which assembles multidisciplinary academics and a number of leave and remain supporters to its work as an independent source of research and analytical reflection on Brexit. ${ }^{25}$ The complexity and intricacy of the range of issues raised is also borne out from an analysis of law firms and chambers in the UK advertising Brexit practices, invariably bringing on board a vast array of personnel and additional interdisciplinary expertise. The multi-disciplinary nature of Brexit is important to acknowledge, and is both welcome and testing at the same time. It is welcome, because questions of the implications of Brexit are not solely legal questions, but rather, as argued in this collection, much of the debate on Brexit has been (certainly implicitly, if not expressly, framed as) about questions of justice in society, which pertains to non-legal concepts, critiques and judgements. At the same time, this is testing because law and legal research must challenge itself, methodologically, to answer these questions. This raises questions of research design, extra-legal expertise and the appropriate utilisation of the research outcomes. ${ }^{26}$ Doctrinal research has often been accused of 'neglect[ing] the real world consequences of doctrinal theories', ${ }^{27}$ since it focuses on technicalities and exposition of existing knowledge. However, Brexit has triggered researchers to begin from a 'world' challenge as a basis for research. This book is a modest contribution to raising awareness of how legal researchers approach their topics from that world problem starting point.

Contributors are asked a series of questions on their understanding of justice in their chapter:

- What does justice or injustice mean in your research?

- Whose justice is affected in your case studies?

- Does the notion/your perspectives of justice in Brexit change depending on your case study?

See The UK in a Changing Europe: http://ukandeu.ac.uk/.

26 See further, Rob van Gestel and Hans-Wolfgang Micklitz, 'Why Legal Methods Matter in European Legal Scholarship', (2014) 20(3) European Law Journal 292-316 at $301 \mathrm{ff}$.

27 Ibid., at 293. 
- Is it possible to be objective in your research as to the question of the justices or injustices of Brexit?

We also asked participants the following series of questions as a means of framing the challenges of Brexit:

- How do you frame issues of injustice generally? Are they procedural or substantive? Methodological? Normative?

- How do 'binary' framing issues impact on your work?

- How do you engage with issues of novelty surrounding exit from an international organisation?

Furthermore, we asked participants the following series of questions as to methodology and Brexit:

- Is your over-arching normative point influenced by any methodological point?

- What methodological challenges does your case-study hold up?

- What is evidenced-based data in your work? What do you regard as independent or objective evidence as to Brexit? Whose perspective governs how you engage with this/outline it?

- Do socio-legal issues inform your own understanding of your methodology?

- How is impact and effect framed in your work?

This takes us onto broader issues of framing, beyond methodological issues.

\section{FRAMING JUSTICE AND SOVEREIGNTY CLAIMS IN BREXIT}

A broader methodological challenge is to engage with how sovereignty has been a dominant feature of the Brexit debate and remarkably central to justice issues. It stands also as one of the most non-conclusive and conflicted issues as to EU integration, and operates as a de facto and de jure framing 'shadow'.

The UK's vote on 23 June 2016 to leave the EU is a very important study in the idea of how the nation state engages with sovereignty. It is probably also a useful examination of the significant conflict between the nation state, globalisation and the global legal order. It is a difficult 'take' on the notion of contemporary sovereignty. Britain has always famously been 'the awkward partner' of Europe in the eyes of many. ${ }^{28}$ Contemporary historians claim that Brexit is a rather more recent step in the UK's efforts to proactively influence

28 Stephen George, An Awkward Partner: Britain in the European Community ( $3^{\text {rd }}$ edn, OUP 1998). 
European cooperation. Rather, most instances of its isolationism in the past were self-induced and there are multiple legacies of UK influence on economic policy, sometimes quite protectionist. ${ }^{29}$ On whatever view, the UK has always had a rather muddled history in its attempts to join the EU - vetoed by the French in 1963 and 1967 on the basis that the UK saw the (then) EEC primarily as a trading bloc and was insufficiently committed to the broader project of European integration. It is also a striking example of the contours of contemporary sovereignty and perhaps also British exceptionalism. Some suggest that it is a very unsurprising outcome when a longer-term perspective is taken on the trajectory of EU integration since 1973, which has evolved radically since then from a common market project. It moves away from the view that internationalisation and global cooperation is a fait accompli of contemporary times and fits in with the narrative of Trump and other sources of rising nationalism. ${ }^{30}$ The preamble to the Treaty of Rome establishing the European Economic Community in 1957 resulted in the six original signatories to the Treaties declaring that they were determined to lay the foundations for an ever-closer union among the peoples of Europe. By the time a vote had been put to the peoples of the UK in June 2016, a diversity of 'concessions' negotiated by the UK with the EU to roll back the full weight of the free movement of persons, in particular, did not achieve popular or political agreement. ${ }^{31}$ Brexit was the culmination of over 40 years of difficult membership of the EU for the UK,

29 Laurent Warzoulet 'Britain at the Centre of European Cooperation (1948-2016)' (2018) 56 JCMS 955.

${ }^{30}$ Christophe Hillion, 'Leaving the European Union, the Union Way: A Legal Analysis of Article 50 TEU' (2016) 8epa SIEPS 1; Christophe Hillion, 'Accession and Withdrawal in the Law of the European Union' in Anthony Arnull and Damian Chalmers (eds), Oxford Handbook of European Union Law (OUP 2015); Christophe Hillion, 'Accession and Withdrawal in the Law of the European Union' in Carlos Closa (ed), Secession from a Member State and Withdrawal from the European Union: Troubled Membership (CUP forthcoming); Heather Hofmeister, 'Should I Stay or Should I Go? - A Critical Analysis of the Right to Withdraw from the EU' (2010) 16 Eur L J 589; Paul Craig, 'Brexit: A Drama in Six Acts' (11 July 2016) ELRev (August 2016) Oxford Legal Studies Research Paper No. 45/2016, http://ssrn.com/abstract= 2807975, accessed 20 October 2018.

31 European Council, A New Settlement for the United Kingdom within the European Union [2016] OJ C69I/16 1-16, http://eur-lex.europa.eu/legal-content/EN/TXT/?uri =uriserv:OJ.CI.2016.069.01.0001.01.ENG\&toc=OJ:C:2016:069I:TOC, accessed 20 October 2018; Joint statement by the EU leaders and the Netherlands Presidency on the outcome of the UK referendum on 24 June 2016, https://www.consilium.europa .eu/en/press/press-releases/2016/06/24/joint-statement-uk-referendum/pdf, accessed 20 October 2018; Informal meeting of the European Council 29 June 2016, Statement, https://www.consilium.europa.eu/media/20462/sn00060-en16.pdf, accessed 20 October 2018; Council Decision (EU) 2016/1316 of 26 July 2016 amending Decision 2009/908/EU, laying down measures for the implementation of the European Council 
which has long been regarded as a laggard, outlier or troublesome member, with constantly wavering public support for its internal market and reasonably consistent opposition to political and economic integration of other sorts. ${ }^{32}$ The underlying contestation of sovereignty has been constant and ongoing in the evolution of the relationship and has never abated, however constructed.

Brexit has a highly complex history involving the British relationship with Europe over several decades, constantly marked by exceptionalism, opt outs, or referenda. 'Punch drunk' on sovereignty is how some have depicted Brexiteers, suggesting the intoxication of sovereignty as an idea and a fantasy in a globalised world where transnational cooperation is self-evidently necessary for a large amount of trade and services. Some even argue that leaving the $\mathrm{EU}$ is one of the most protectionist acts in the UK's history, where it seeks not to be part of either a customs union or a single market of half a billion consumers. ${ }^{33}$ The mantra of 'take back control' was a core slogan of the Brexit 'Leave' campaign. The decision to leave the customs union and single market is taken with the intent of being free to negotiate trade deals with all of the world.

The alleged incompatibility of the freedom of movement of persons with the dissatisfied post-industrial northern economic blight might be one explanation of the Brexit vote. The perceived incompatibility of migration with British 'sovereignty' arising from overwhelmed public services unable to cope with influxes of foreigners or the alleged undercutting of British jobs by foreign workers is another. A large number of the substantive justice versus injustice concerns outlined in the methodology section above pertain to this. A further might be the intoxicating cry of 'taking back control' in response to the perceived restraint of European laws upon the sovereignty of the Member State(s), but again, this is only an incomplete explanation of Brexit. The geo-

Decision on the exercise of the Presidency of the Council, and on the chairmanship of preparatory bodies of the Council OJ L208/42; Craig (n 30).

32 Allen Neely, 'British Resistance to European Integration: An Historical and Legal Analysis with an Examination of the UK's Recent Entry into the EMS' (1991) 10 Penn State Intl L Rev 113; Patrick Le Galès, 'UK as an Exception or the Banal Avant Garde of the Disintegration of the EU' (2016) 87 Socio-Economic Review 42; Helen Wallace, 'Possible Futures for the European Union: A British Reaction' Harvard Jean Monnet Working Paper No. 7/00 Symposium: Responses to Josckha Fisher, https://jeanmonnetprogram.org/archive/papers/00/00f0701.rtf, accessed 20 October 2018; Catherine Barnard, 'The Opt-Out for the UK and Poland from the Charter of Fundamental Rights: Triumph over Rhetoric' in Stefan Griller and Jaques Ziller (eds) The Lisbon Treaty: EU Constitutionalism without a Constitutional Treaty (Springer 2008).

33 Damian Chalmers, 'LSE Law Brexit Special \#4: Trade after Brexit' (2017) LSE Law Policy Briefing Paper No. 23, https://ssrn.com/abstract=2941354, accessed 20 October 2018. 
graphical explanation of North versus South, young versus old, rich versus poor, urbanite versus the rest, form again further inadequate and divisionist views on Brexit, but above all entails highly only one consistent factor - that the social changes setting the stage for Britain's historical vote took place some time ago. ${ }^{34}$

A large amount of uncertainty on all sides was evident as to the precise benefits and disadvantages of leaving from an economic perspective. These multiple uncertainties have rolled over into the negotiations as the costs of the so-called 'divorce' bill. The sovereignty 'claim' of Brexit is one of the most vibrant case-studies in contemporary times in the global legal order and thus worthy of considerable study and reflection. Unfortunately, however, it is likely to be a claim which may easily fall short of the desired outcome for those seeking to take back 'control'. Above all, there was no political or bureaucratic planning for a Leave vote and as a result there has been a scramble to amass the detail, procedure and planning needed to execute the perceived outcome of the vote.

We asked participants the following series of questions in this regard:

- How do we understand sovereignty and control in the contemporary global legal order?

- How should we understand British exceptionalism in Europe and its sovereignty claims?

\section{FRAMING THE (RATIONAL) STATE: ON BREXIT}

As already alluded to, as an act of leaving an international organisation which had strong free movement of persons requirements, Brexit brings forth questions of what kind of justice is owed to those outside our state boundaries, and in particular, when persons who have had rights to enter these state boundaries find themselves subsequently unwelcome. The discussion about justice has often been limited to a specific territory, i.e., a nation. ${ }^{35}$ Just as with the question of justice within a nation state, the question of what justice means outside

34 Brendan O'Neill, 'Brexit Voters Are Not Thick, Not Racist, Just Poor' (The Spectator, 2 July 2016), https:/www.spectator.co.uk/2016/07/brexit-voters-are-not -thick-not-racist-just-poor/\#, accessed 20 October 2018; Matthew Goodwin, 'The 2016 Referendum, Brexit and the Left Behind: An Aggregate-Level Analysis of the Result' (2016) The Political Quarterly 1; Robert Ford and Matthew Goodwin, 'A Nation Divided' (2017) 28(1) J of Democracy 17.

35 Goran Collste, 'Globalisation and Global Justice' (2005) 59(1) Studia Theologica $55-72,55$. 
the nation state, and thus whether justice should be blind to the boundaries of the nation state (cosmopolitanism) or should be confined to those geographical territories (statism) is not universal. ${ }^{36}$ Justice issues in globalisation are linked to concerns about 'people at a distance, transcending national borders'. ${ }^{37}$ Justice debates in global governance are also linked to participation in structures outside the state system. As Young explains, links to people at a distance occur through social processes, and institutions are a response to these obligations, rather than their basis. ${ }^{38}$ Systems and fora of international relations, international law, and international organisations, limit the ability of states to act entirely autonomously. Such systems of global governance have been argued to promote justice, but equally have been argued to erode justice, or to cause injustices. The UK's membership of the EU - i.e., its participation in global governance - entailed a European cosmopolitanism, which took the UK out of its nationalist comfort zone.

One of the most elementary features of Brexit has been to map out a new pathway for a state to reclaim its sovereignty having become enmeshed in a supranational legal entity. It poses many questions as to 'rational state' behaviour in the international legal order and also in particular issues of compliance with that order. ${ }^{39}$ Others demonstrate how treaty withdrawal has entered a new constitutional matrix. ${ }^{40}$ This confidence now appears increasingly fallacious. Instead, the era of exit from international organisations is exemplified by the Trump Administration; UK, EU and ECHR planned exits; and exits by African countries from the International Criminal Court, and marks an important shift in considering the behaviour of states at a global level. ${ }^{41}$ In this new era, the idea of the rational state actor is a much more complex and nuanced construct. It entails that a range of lenses and perspectives may readily be adopted as to what Brexit is and how it may be devised.

36 Laura Valentini, Justice in a Globalized World: A Normative Framework (OUP 2011).

37 Collste (n 35), 55.

38 'All agents who contribute by their actions to the structural processes that produce injustice have responsibilities to work to remedy these injustices' from Iris Marion Young, 'Responsibility and Global Justice: A Social Connection Model' (2006) Social Philosophy and Policy Foundation 102-30, 102. See further, 'we have obligations to those who condition and enable our own actions, as they do to us' (at 106).

39 Louis Henkin, How Nations Behave: Law and Foreign Policy $\left(2^{\text {nd }}\right.$ edn, Columbia University Press 1979) 47 cited in Jeffrey Dunoff and Mark Pollack, 'Experimenting with International Law'(2017) 28 EJIL 1317.

40 P-H. Verdier and M.Versteeg, 'Separation of Powers, Treaty-Making, and Treaty Withdrawal: A Global Survey' in C. A. Bradley (ed) Oxford Handbook of Comparative Foreign Relations Law 2019, (forthcoming).

${ }_{41}$ Daniel Francis, 'Exit Legitimacy’ (2017) 50 Vand. J. Transnat'l L 297. 
Scholars of EU and Public international law have advocated to engage more with the constructivist challenge of Brexit, as a disruptive shift in EU-state dynamics that can only be managed through a radical rethink of its multi-level components, in trying to fight it out. For example, Weiler has sought to argue vociferously for a kinder and gentler Brexit. ${ }^{42}$ Alternatively, Streinz has argued for the inverse application of sincere cooperation to attempt more actively to accord the UK greater competences to facilitate its desire to negotiate trade deals. ${ }^{43}$ The range of nuanced opinions as to how to depict the rationality of the UK in its statist aspirations is of much significance here for our methodological lens. It demonstrates principally that the constructivist challenge of understanding the 'rational state' in contemporary times is more of an art than a science and that the subjects and objects of EU action shift greatly depending upon voice, time etc. Any challenge to the precepts of rational behaviour perhaps all too quickly presupposes its irrationality and its exceptional casual implications. As Francis argues, exit from international organisations has entered a new legal and political era as a coming of age. ${ }^{44}$ It is a context of shortcomings, weaknesses, purely hypothesised observations and difficult causal constructions. It is not a context that facilitates easy analysis thereof and has distinctive legal and political analytical strands. ${ }^{45}$

These challenges have manifold consequences for analysis at micro level. Specifically, how to unpack the methodological questions of justice and injustice as to Brexit? This alone at macro level is a feat, yet alone micro level.

We thus asked contributors the following questions:

- How do you view the rational state?

- What is behavioural in your analysis?

- How do you engage with international organisations in your work?

Beyond sovereignty claims, we seek to reflect upon the conceptual notion of actorness in Brexit. Aspects of the political campaign to leave the EU may be said to be highly aligned with specific actors, who have set in motion a series of debates triggering the questions and issues arising for discussion here. It is thus from a scientific perspective use to seek to isolate the concept of actors here.

42 Joseph H.H. Weiler, 'Editorial: The Case for a Kinder, Gentler Brexit' (2017) 15(1) Intl J of Constitutional L 1.

43 Thomas Streinz, 'Cooperative Brexit: Giving Back Control over Trade Policy' (2017) 15(2) Intl J of Constitutional L 271-90.

44 Francis, (n 41); Laurence R. Helfer et al,. 'Treaty Exit at the Interface of Domestic and International Law' (2017) 111 AJIL 425.

45 Andrew Gamble, 'Taking Back Control: The Political Implications of Brexit' (2018) 25(8) J of Eur Public Policy 1215. 


\section{FRAMING THE ACTORS OF BREXIT}

Actors arguably play a significant role in the question of whether Brexit is just or unjust. Thus, there is the question of withdrawal from the EU, and with which actor lies the prerogative to conduct this act. ${ }^{46}$ The Miller case recognised that the rights created by EU law meant that Parliament and not the Executive had to authorise withdrawal from the EU. This recognition was premised on the idea of justice for the individuals who currently rely on EU law rights, many of whose democratic voice is exercised through Parliament. In addition, concerns are raised around whether the withdrawal agreement would be an international agreement and therefore it and the rights therein subject to potential repeal, unless they are entrenched into UK law. ${ }^{47}$ Would individuals secure their rights in the withdrawal agreement before an international tribunal, having exhausted domestic remedies? There is also the question of what rights would remain for individuals, and how they would be protected. ${ }^{48}$ As for the rights, the loss of EU rights would certainly deprive categories of EU citizens in the UK and UK citizens across other EU member states of their EU law rights. Contrarily, EU nationals who have resided in the UK for decades, are married to British citizens and have children who are UK nationals received letters from the Home Office stating that they ought to make plans to leave. Additionally, those officially recognised as permanent residents are likely to suffer even more bureaucracy and uncertainty following the need to register in some form under a new system. ${ }^{49}$ Particular concerns surround the separation of families, and also for the increase and unfairness of deportation orders..$^{50}$ Brexit has already led to premature departures of EU citizens from the UK. ${ }^{51}$

The framing tool of the subjects and objects of EU law may usefully be deployed in these questions to consider the conceptual challenges of Brexit and its construct. ${ }^{52} \mathrm{It}$ is a procedure with unique subjects, internal to the UK, both

46 For various discussions, see Catherine Barnard, 'Law and Brexit' (2017) 33(1) Oxford Review of Economic Policy 4-11.

47 Which would be difficult because of UK constitutional law, Paul Daly, Kirsty Hughes and Kenneth Armstrong, 'Brexit and EU Nationals: Options for Implementation in UK Law' CEPS/CPL Working Paper Nov 2017 1-14.

48 Ibid.

49 House of Commons Exiting the EU Committee, 'The Government's Negotiating Objectives: the Rights of UK and EU Citizens' (para. 98) in Kirsty Hughes, 'Brexit and the Right to Remain of EU Nationals' (Nov 2017) (Brexit Special Extra Issue) Public Law 94-116.

50 See further, Adrienne Yong in this collection.

51 Hughes (n 49).

52 Samo Bardutzky and Elaine Fahey (eds), Framing the Subjects and Objects of Contemporary EU Law (Edward Elgar 2017), Introduction. 
EU and UK citizens alike. For example, its subjects may also be said to be the EU and UK itself. UK citizens in the EU may be said to form a cohort as the objects of EU law. Third-country national family members and dependants, etc of EU nationals in the UK also form another cohort arguably the objects of Brexit. Businesses in the UK and EU affected by Brexit may fall into a range of categories, which will increasingly proliferate. Reflecting upon the subjects and objectives of Brexit may lead us to deduce a wider and more complex overlapping set of entities with interests and stakes in Brexit. It is but one example of a framing device which seeks to capture the increasingly broad subjects and objects of EU law. What may be said to be striking about existing scholarship on Brexit which outlines injustice is that it is overwhelmingly citizen-centric literature, which focuses upon the individual, the citizen, and their lost rights.

Part of the challenge methodologically of framing, taming, or naming Brexit as an intellectual process is that it has multiple subjects and objects. The UK itself will in theory transform from a subject of the Treaties qua member state into an object of EU law. However, its likely convergence with EU rules in the future, along with its containment of the EU acquis in its domestic laws, will entail that its separation from the EU will be far from perfect or complete and is likely to amply display strong streaks of subject and object in its future relationship. Straightforwardly, the likely overlap of its place as a former member state will be complex and reflect its tangled history. A 'state-centric' view of Brexit is, however, only one perspective; the place of the individual arguably constitutes a different view thereof. A key innovation of EU constitutional law with respect to public international law has been its radical attachment to realising rights for citizens as the subjects of EU law, thereby making a sharp break from public international law. EU citizens in the UK will become a distinctive and different set of subjects of a Withdrawal Agreement, with nuances in terms of temporal rights, their adjudication, enforcement and their shifting statuses over time. It remains to be seen what statuses UK citizens in the EU will be able to retain. UK and EU businesses, traders, companies, corporations etc also constitute a distinctive demographic or constituency who will also experience shifts in status depending upon the nature of the agreement reached and the alignment of the UK to EU rules.

We proposed the following set of questions to contributors:

- Who do you understand to be the actors who are the central subject and object of Brexit? How does the delineation of actors assist you or hinder your work?

- Are there overlapping subjects and objects in your work? What causes this overlap? How can you reflect more explicitly upon this overlap? 


\section{THE CHALLENGES OF RESEARCH INTO BREXIT: CONCLUDING THOUGHTS}

The above sections have sought to identify some of the challenges to our (legal) analytical and methodological understanding of the justices and injustices of Brexit. They have made the case that legal issues of Brexit are challenging to explore because of these different approaches, and seek to be more explicit about the existence and nature of these approaches in our study of Brexit. Conceptually, Brexit analysis will lead to an array of conclusions about its justices or injustices because the concept of justice itself is subject to a range of interpretations and starting points. Brexit also entails significant elements of mystery and unpredictability, given that, unlike the general trend of EU studies to date which have concerned our understanding of the creation and strengthening of participation in international organisations, we are exploring the novel perspective of withdrawal from an international organisation. Methodologically, Brexit analysis is testing, because to understand Brexit from the perspective of justice, will often require approaches beyond a traditional doctrinal one, and require legal researchers to embrace more complicated multidisciplinary research methods.

As an act of withdrawal from an international organisation, Brexit provokes further critique of the importance of national sovereignty in the twenty-first century. While we have seen, in recent years, a proliferation in participation in international organisations and exit therefrom or defunding thereof (e.g., from the International Criminal Court to the World Trade Organization), Brexit is a stark reminder that this trend cannot and must not be taken for granted but is also taking place in parallel with many other populist movements against international organisations. Brexit thus requires us to take even more seriously the need to critique the means through which actors in national and international contexts can achieve their common goals, while facing ongoing hostility from the very partners purporting to be part of the common group. Likewise, debates on Brexit remind us that, in assessing justices and injustices, the state is not only - or predominantly - seen through the lens of the geographical nation, but that a fuller critique cannot ignore the transnational dimensions to the state. Finally, our understanding of the challenges of Brexit must also consider - and are influenced by - our perspectives on the relevant actors, be they subjects or objects, or perpetrators or victims.

Sections I-IV have explored a few - by no means - exhaustive - ways in which Brexit is intertwined with ideas of justices and injustices. The remainder of the book consists of more detailed exploration of some of the sub-topics of the Brexit debate. They cover issues from trade to human rights, from labour to health, from national sovereignty and geographical territory, to our under- 
standing of the national and supranational in today's globalised world. We turn now to an introduction to each of the remaining substantive chapters of the book.

\section{ORGANISATION OF THE BOOK PROJECT}

The book is organised into three distinct sections, correlating to the four thematic strands outlined here, which the contributing authors have been asked to address throughout their contributions where feasible. Overall, Part I considers aspects of governance and Brexit and draws upon the broadest thematic strands and widest notions of justice and its public administration. Part I includes a diversity of perspectives on theoretical aspects of justice and injustice and the relationship between the analytical and methodological. Part II analyses citizens' and vulnerable persons' rights and Brexit and sets out a range of case studies which reflect upon practical issues and implications for individuals. This Part sets out many case studies pertaining to the diverse subjects and objects of Brexit, all of which engage explicitly with the thematic strand, while Part III assesses globalisation and Brexit, and engages in holistic assessments of contemporary global trade, political theory and globalisation with respect to Brexit. There, contributors assess in general terms the geopolitical understandings of Brexit with respect to justice, taking a large-screen lens at the nature of statehood in the global legal order and the action of exit from a supranational organisation.

An outline of chapters per section follows next.

In Part I, Whose and Whither Justice after Brexit Seymour's argument is two-fold. He first argues that Lexit fails in its critique of the EU, because it is divorced from social relations, and this mystifies its perceived problems of the EU. For instance, Lexit's use of the concepts 'financialisation' to denote the EU as a neo-liberal order, and to suggest that it represents the whole of the EU. Likewise, Lexit presents the terms 'elite', 'British people' and/or 'British workers' as epitomising external forces bearing down on vulnerable labourers, and as homogenous categories of people, absent of the realities of conflicting interests. Seymour's second argument is that consequently, the remedies advocated by Lexit risk reproducing the perceived problems identified.

Kukovec argues that Brexit is not a departure from existing thinking about the EU, and is a symptom and consequence of lawyers' deficient historical constitutional discourses on it. Building on theories concerning law professionals' duties to their clients, Kukovec argues (expanding upon these premises) that through the remain campaign and literature, lawyers have failed to meet their duty to provide analytical clarity about law and society to politicians and to society. 
O'Connell argues that the Brexit vote was a reaction against forms of injustice which the EU systematically produces, and which it has enshrined into its core constitutional architecture, crucially as to economic and monetary policies and their impact nationally. For him, Brexit provides a constitutional framework which reproduces and legitimates stark injustices between and within the member states of the EU. That the Brexit vote was, in part, a rejection of this constitutional settlement, in principle the Brexit rupture opens up space to pursue more expansive projects of justice in the UK and across Europe.

In Part II, Brexit and Governance, Grogan critically evaluates the Brexit process from the perspective of the future of vulnerable categories of rights, establishing the inevitable and negative impact of the Brexit process on the framework of rights protection in the UK. The chapter highlights the weakening at the foundation of equality, worker and consumer rights, and the acute vulnerability of 'new' rights, which are significantly and substantially weakened.

Powell examines the concept of sovereignty across the development of Brexit and argues that a shift can be seen from the traditional notion of parliamentary sovereignty to one of sovereignty of the people. The challenge to parliamentary sovereignty can be seen where referenda are utilised in the UK, particularly recently, since 2010 . With specific reference to the Brexit referendum of 2016, Powell argues that the discourses of 'legitimacy' and the 'will of the People' availed of by the Leave campaigners made distinct attempts to shift the idea of sovereignty from that of Parliament to 'The People'.

Douglas-Scott continues the critique of sovereignty, brandishing the UK for taking a decision to leave the EU based on misunderstood and incoherent conceptions of sovereignty. Supranational organisations, like the EU, Douglas-Scott argues, can in fact empower a state, and thus her sovereignty. Likewise, parliamentary sovereignty in the UK is a contested notion, and did not, in all circumstances, operate in its classic form, and popular sovereignty has not yet developed to overtake parliamentary sovereignty. As a result, the idea of leaving the EU to 'take back control' is premised on unclear grounds and, moreover, could in fact be seen to threaten the UK's national sovereignty.

Odermatt examines the role of the Court of Justice of the EU in achieving justice. Justice, he argues, is both about the processes and the identity of the decision-maker. In 'taking back control', the UK asserted that justice cannot be served by 'foreign' judges based in Luxembourg. Consequently, the focus of the Brexit Withdrawal Agreement on power sharing between the two layers of authorities has taken precedence over the needs of procedural justice for individuals.

In Part III, Citizens and Vulnerable Persons, Yong argues that human rights enforcement and adjudication in the Brexit process is one factor that indicates whether justice can be achieved in a post-Brexit Britain. EU citizens in the UK 
face significant effects on their private and family lives, particularly as regards their residency status in the UK.

Polak considers how the 2016 referendum vote to leave the EU was highly influenced by the levels of immigration caused by free movement. The chapter seeks to analyse how just the current system of freedom of movement in the EU is and, building on that result, to question whether the UK's withdrawal from this specific principle and concept can be understood to be just or not, reflecting upon the multiple constitutencies at play.

Germain explores and critically analyses whether more justice in health care will arise out of the new relationship between the UK and the EU after Brexit, or whether challenges will create more injustice inside and outside of the NHS, in the sense of distributive justice, as seen through the lens of the foundational egalitarian principles of the NHS.

Xanthopoulou considers how the UK will no longer be bound by EU minimum standards of protection under the first phase of legislative measures that the UK had opted into. The chapter, also, observes that it is unlikely for the UK to continue participating in the CEAS, despite the fact that this has been so far beneficial for the UK. It is suggested that if the UK wishes to participate to the CEAS, it should offer legal certainty, in a true spirit of solidarity and to ensure the protection of rights at an equal level as the EU law provides for.

In Part IV, Territory and Globalisation, McDonagh probes how the ongoing Brexit process has profound consequences for Northern Ireland within the constitution of the United Kingdom of Great Britain and Northern Ireland. McDonagh explores how the Brexit process has reopened apparently settled questions on the constitutional status of Northern Ireland, such as the viability of the post-1998 power-sharing institutions and has allowed the question of whether a referendum on reunification with a united Ireland should be called to resurface.

Skoutaris maps the challenges that Brexit might pose to peace and to the question of sovereignty. He first argues that the potential hardening of the borders as a result of Brexit threatens the cross-border cooperation that underpins the current fragile status quo related to Northern Ireland and the Sovereign Base Areas in Cyprus. In the Withdrawal Agreement, in the case of Cyprus, the UK SBAs are to be appended to the list of regions of third countries that are part of the EU customs territory with relatively little objection. The Irish backstop has suffered from significant opposition. However, Skoutaris argues that a differentiated Brexit does not necessarily undermine the UK's Constitutional integrity.

Bardutzky explores whether the reason for Brexit can be found in political constitutionalism, in critiquing its ability to accommodate for the participation of a nation in supranational projects. The starting point of the contribution is precisely the idea of the subjectivity of an EU member state as the potential 
to (co-)author law, shape, define and influence policies, as well as engage in relations with other subjects (inter-subjectivity). Brexit offers us a so far unique opportunity of what happens to the subjectivity of a nation (within the EU, internally, and beyond) as it traverses from member state to third country.

Collins explores the concept of trade justice for an independent trading entity in the global legal order. The UK should be able to negotiate FTAs with third states during a transition period as long as they do not go into effect before actual departure and provided that an actual FTA with the EU is forthcoming. Negotiating new FTAs with third states could require divergence from EU standards in some circumstances along with low tariffs on many sectors, compelling the UK to make critical choices about which foreign markets it seeks closest alignment as well as the type of economy it wants at home.

Corkin argues that while cosmopolitans might find common cause with non-nativist communitarians who emphasise the significance of democratic self-determination within national political communities by recognising the historical contingency of their communities, which points to their capacity to change but also that they can only be expected to move so far, so fast. Cosmopolitans might prefer everyone to extend their horizons to become as cosmopolitan as they are, but must accept that, for as long as many continue to hold their local identities dear, politics has primarily to be organised locally, albeit within political communities that are inclusive (non-nativist) and outward looking. And to look outwards means they have no choice but to interact with one another in multi-level orders that manage their factual interdependence.

\section{CONCLUSION}

As the heated discourses surrounding the UK's EU referendum vote demonstrated, a wealth of diverse, diverging and contradictory perspectives exist around what Brexit constitutes and the putative or likely impact Brexit will have on individuals and groups, most of which may not be fully measurable for a very long time. Analyses of Brexit in legal studies brings up questions surrounding both substantive claims regarding the justices and injustices of Brexit, as well as about the robustness of our methodological approach to this contemporary and highly complex and divisive process.

The novelty of issues surrounding exit from international organisations indicates on a wholly practical level the novelty of framing rational state behaviour in a broader context. Brexit has a range of binary frames: its vote; its negotiation sparring partners; its opposing view of divergence and convergence of EU and UK law going forward on socio-economic terms which necessitate wider lenses. To frame Brexit arguably entails seeking an objective understanding 
of its meaning or its core. We argue that methodologies of justice provide a 'thick' substantive core for this exercise.

Brexit provokes us to consider the consequences of global governance for justice at national and international levels, as well as vice versa, the effects of national level ideals of justice on global governance, and this project thus attempts to engage at many levels with frames and paradigms, as to the state in the contemporary legal order, globalisation and sovereignty, amongst other themes.

This project thus seeks overall to make more explicit the methodological and analytical tools used in legal studies on Brexit, and thus to shed light on the strengths of our critiques on who and what Brexit is a just option for. The book project has methodology central to its core. It thus renders the project less time-bound and more inter-disciplinary and multi-disciplinary, thereby enabling deeper engagements with others, within the UK and well beyond. 